УДК 811.161 .2

С. А. Шуляк

\title{
ОСОБЛИВОСТІ ПОВТОРУ В ТЕКСТАХ УКРАЇНСЬКИХ ЗАМОВЛЯНЬ
}

Шуляк С. А. Особливості повтору в текстах українських замовлянь.

Стаття присвячена дослідженню лексичного та синтаксичного повтору в текстах українських народних замовлянь. Проаналізовано особливості функціонування цих видів повтору як структурно-семантичного засобу організації замовних текстів. Розглянуто логічний зміст, граматичну зумовленість використання повтору в структурі замовлянь.

Ключові слова: лексичний та синтаксичний повтор, семантика, українські замовляння, текст.

Шуляк С. А. Особенности повтора в текстах украинских заговоров.

Статья посвящена исследованию лексического и синтаксического повтора в текстах украинских народных заговоров. Проанализировано особенности функционирования этих видов повтора как структурно-семантического средства организации заговорных текстов. Рассмотрено логическое содержание, грамматическую необходимость использования повтора в структуре заговоров.

() С. А. Шуляк, 2015. 
Ключевые слова: лексический и синтаксический повтор, семантика, украинские заговоры, текст.

Shulyak S. A. The peculiarities of repetition in the texts of Ukrainian spells.

The article is devoted to the research of lexical and syntactic repetition in the texts of Ukrainian folk spells. We analyzed the peculiarities of functioning of these kinds of repetition as a structural-semantic means of the text organization. We learned logical content, grammatical reasons of using repetition in the structure of spells.

Key words: lexical and syntactic repetition, semantics, Ukrainian spells, text.

Важливим аспектом дослідження сучасного мовознавства $\epsilon$ визначення особливостей текстотворення українських народних замовлянь. У зв'язку 3 цим потребують вивчення лексичний i синтаксичний повтор як засоби зв'язку у цих фольклорних текстах.

Художній прийом повтору на матеріалі художніх творів розглядають М. Алефіренко, Ж. Гетьман, Т. Зайцева, А. Коваль, А. Мойсієнко, О. Пивоваров, М. Плющ, С. Скляр, О. Тараненко, О. Фоменко та ін.

Повтор як засіб посилення експресивності оповіді вивчають М. Астаф'єва, Н. Арутюнова, Л. Балясна, П. Вдовиченко, В. Єрьоміна, Н. Змієвська, Є .Іванчикова, Є. Кисловська, Н. Кожевникова, О. Огай, Г. Петровичева, О. Світлична.

О. Потебня надавав повтору особливої уваги, вважаючи, що збільшення вживання в мовленні того самого слова дає нове значення, об'єктивне або суб' єктивне [4, с. 552].

Т. Жук досліджує лексичний та синтаксичний повтор на матеріалі українських народних казок, зазначаючи, що різні види лексичного повтору репрезентують специфічні семантико-стилістичні функції: виділення найістотнішого в описуваних подіях, стилізації часових параметрів їх розгортання та інтенсивності (дієслівний повтор); кількаразового іменування особи з метою іiі характеризації (номінаційні ланцюжки, прикметниковий синонімічний та антонімічний повтор), вираження емотивної семантики - психічного стану дійових осіб, емоцій, переживань тощо [2, с. 7], а синтаксичний повтор у структурі казкового тексту взаємодіє з просодичними засобами мови, роль яких полягає у вираженні смислових, експресивно-емоційних, модальних характеристик речень (висловлень) та стилістичного варіювання [2, с. 12].

Повтор - це фігура мови, що полягає в повторенні в певній послідовності звуків, слів або їх частин, висловів для досягнення відповідного виражального чи виражально-зображуваного ефекту [7, с. 459].

У «Словнику тропів і стилістичних фігур» (2011) повтор - це 
повторення слів або словосполучень, часом у видозміненому вигляді, задля того, аби затримати увагу на певній важливій думці [5, с. 135].

Оскільки особливості повтору в текстах українських народних замовлянь дотепер не були об'єктом спеціального вивчення, тому метою нашої статті є дослідження особливостей лексичного та синтаксичного повтору у текстах українських народних замовлянь. Досягнення поставленої мети стає можливим за умови виконання таких завдань: проаналізувати види повтору як структурно-семантичного засобу організації замовних текстів; розглянути логічний зміст, граматичну зумовленість використання повтору в структурі текстів замовлянь.

Міфологічний період, як один 3 найтриваліших і найважливіших у людському поступі, характерний для кожного народу; це значить, що кожний народ пережив період богів, напівбогів, титанів, велетнів, драконів (добрих i злих), створивши собі заміщений світ, у якому людина спілкувалася із сонцем, місяцем, зірками, добрими і злими духами, а оскільки залежала від них, то створила цілу систему магічно-ритуальних дійств з метою задобрити чи нейтралізувати ці сили природи, умилостивити їх, щоб спиратися на їхню допомогу [6, с. 264]. Так, на повтор натрапляємо в замовляннях, де ведеться розмова 3 місяцем, у якій за допомогою формули обміну тобі - мені людина набуває собі здоров'я, як-от: Місяцю, місяцю молодий, / у тебе ріг золотий, / тобі на підповня, /мені на здоров'я [1, с. 10].

Важливе місце у світорозумінні та уявленнях українців посідають численні вірування у різні прикмети, силу чарів та замовлянь, добру та лиху годину, щасливе й нещасливе місце, доброго «полазника», легкі і тяжкі дні тощо [6, с. 253]. У текстах деяких замовлянь присутні елементи молитов, наприклад: Хто буде мою молитву сповняти, / Не буде у вогні погоряти, / Не буде у воді потопати, / Не буде звір поїдати, / Не буде наглою смертю помирати [1, с. 21].

У текстах замовлянь трапляються такі типи повторів: самостійних частин мови (іменників, дієслів, займенників, числівників, прикметників), службових слів, вигуків, усталених сполучень слів, словосполучень, підрядних фразеологізованих словосполучень тощо. Тож розглянемо їх.

Найпоширенішим із повторів самостійних частин мови $\epsilon$ іменниковий, наприклад: Болячка польова, болячка віхрова, / Болячка навіяна, болячка вітрова, / Болячка навіяна, болячка набродяна, / Болячка наспана, болячка наслана - / Я тебе вимовляю, на сіль виганяю... [1, с. 32]; Болячка гнила, / Болячка пухка: / Болячка з ружі, / Болячка з марени, / Болячка з лихим часом, / Болячка з гістием, / Болячка з роботи, / Болячка з охоти, / Болячка з уроків, / Болячка з лихої волі, / Болячка наслана, / () С. А. Шуляк, 2015. 
Болячка прислана, / Болячка вітрова, / Болячка польова! [1, с. 28]. Іменні лексеми використовуються в текстах українських замовлянь як стилістична фігура, наприклад: Гора з горою, камінь з травою, риба з водою! [3, с. 23].

Дієслівний повтор у замовляннях, як-от: Виходьте, страхи! / Виходьте, ляки! / Виходьте, переляки. / Виходьте, навї! / Виходь, злий $\partial y x ![1$, c. 18] $є$ одним із найважливіших засобів спонукання до дії. Надзвичайну силу впливу на адресата мають замовляння, у яких поєднується повтор іменників та дієслів, наприклад: Уроки, урочища, чоловічі й жоночі, дитячі, вам, уроки, урочища, у раба Божого (...) не стояти, жовтої кості не ламати, червоної крови не пити, серия його не нудити, білого тіла не сушити... [3, с. 34];

Повтор займенників у замовляннях зазвичай пов'язаний 3 необхідністю приховування справжнього ім'я людини, щоб не дізналися злі духи. Присвійний займенник її є частотним у замовних текстах на кшталт:

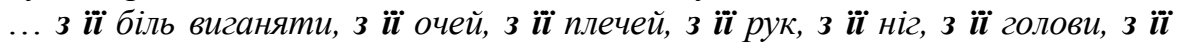
плечей, з іï 77 суставц̧ів [1, с. 30]. Займенниковий повтор виконує анафоричну роль у замовляннях-звертаннях 3 питальним відтінком, наприклад: Чи ти ляк, чи ти не ляк, чи ти подуманий, чи ти погаданий, чи ти примовлений, чи ти приговорений, чи ти чоловічий, чи ти жіночий, чи дитячий, чи дівочий, чи хлоп'ячий, чи всіх людей, чи всіх звірів? [1, с. 36]; Чи ти дівоџький, чи ти парубоцький, чи ти жіночий, чи ти чоловічий, чи ти водяний, чи ти насланий, чи ти заспаний? [3, с. 29].

У текстах українських замовлянь також зустрічаються повтори числівників. Слід зазначити, що фігурують вони в основному в поширених конструкціях поряд 3 дієсловами та іменниками, де повторюються навіть суфікси та закінчення, як-от: Буду тебе карати / Дев'ятьма птахамиперваками, / Дев'ятьма індиками-перваками, / Дев'ятьма гусакамиперваками, / Дев'ятьма качурами-перваками, / Дев'ятьма півнямиперваками, / Дев'ятьма курами-перваками, / Дев'ятьма звірамиперваками, / Дев'ятьма биками-перваками, / Дев'ятьма кіньмиперваками, / Дев'ятьма псами-перваками, / Дев'ятьма котамиперваками, / Дев'ятьма голками буду колоти, / Дев'ятьма косами буду стинати / Дев'ятьма серпами буду зрізати [1, с. 24].

Службові слова використовуються як засіб для перелічування: Де вітер не віє, / Де сонце не гріє, / Де глас Божсий не заходить, / Де престоли не стоять, / Де дзвони не дзвонять, / Де собака не бреше, / Де дівка коси не чеше... [1, с. 16]; Як топиться віск на грані, як сіль на воді, як розходяться хмари на небі, то так ия бола має пропасти від (Віри) хрещеної [1, с. 14]; Броди розширяти, -/ Які заглибокі, / Які заширокі [1, с. 
28]. Прийменники через, від також вживаються у замовних текстах, як-от: Через річку бистру $і$ через кладку хистку йшло три матінки, три п'ятінки (n'ятнииі) [1, с. 30]; Щезни, пропади від (Віриноі) крови, від тіла білого, від (Віриного) ім'я [1, с. 14]; Січіть, рубайте, / Від мира відганяйте, / від раба божсого (Мирослава), / Від онучок, від правнучок, / Від мого чада, від мого стада, / Від всього мира по білому світу! [1, с. 18-19].

Поєднання простих та складних прийменників з іменниками також надають тексту перелічувальної інтонації, як-от: Я тебе, скусо, викликаю від (Віри) хрещеної: з голови, з-під голови, з мозку, з-під мозку, з грудей, 3-під грудей, з серця, 3-під серця, з легенів, 3-під легенів, з печінки, 3-під печінки, з нирок, з-під нирок, з ніг, 3-під ніг, з пальців, 3-під пальців, 3 нізтів, 3-під нігтів [1, с. 13].

Повтор вигуків у досліджуваних текстах виконує функцію переконання та частіше вживається в кінцівці замовляння, наприклад: Дубе, дубе нелине, я тебе з '̈м з гіллям зо всім! Гам, гам, гам! [3, с. 35]; Щоб тут тобі червоної крові не спивати, синих жил не потягати, жовтої кості не ламати. Птфу, птфу, птфу! [3, с. 65]; Хy, ху, ху. / Tьфу, тьфу, mьфy! [3, с. 68].

Для текстів замовлянь характерні усталені сполучення слів, як-от: на віки віків: Життя його благословенне на віки віків! / Потішаю радістю, веселістю, / Бо Бог дає кріпкість на віки віків! Амінь! [1, с. 26]; Водице-здравнице, говірнице, / як ти в Бога славна, / Так аби славен був / Рождений, хрещений (Петро) / Во віки віків! [1, с. 25]; О, віки віков, амінь [3, с. 50] та словосполучення ротом говоритиме: Ротом говоритиме, а губами здуватиме, через тин перекидатиме, щзоб зосталось чисте, як молоко та золото [1, с. 12].

Щоб забезпечити висловлюванню повноту, використовується повтор прикметників, наприклад: Там будеш велике каміння крушити, / Воду переливати, / Піски пересипати, / Дерева крутити, / А до цього красного-прекрасного тіла / Зла не мати [1, с. 23]. Таким чином посилюється ознака образу та надається йому відповідна характеристика.

Повтор розглядаємо як засіб, який надає семантичної зв'язності тексту замовляння на кшталт: $€$ ливада, а на тій ливаді - верба, а під тією вербою сидить дівка розплетена, а в тієї дівки одне око вогненне, а друге водяне [1, с. 12]; Та йшла вона стежкою та дорожкою, та зустрічає ї̈ пристрасть, та взяв ї̈ з плечей, та в ступу вкинув, та товк товкачем - ножем різав, сокирою рубав, а крикнув (ім'я) - та до Господа Бога пішов слух [1, с. 12].

Функціонуючи в тексті, повтор ефективно відображає зміст ๑) С. А. Шуляк, 2015. 
висловлювання: Водичко-Йорданичко, омивай $і$ зиіляй. / Їк ти чіста, їк ти свята, / Так $і$ иеса раба Божа рщена-порожена, / В святій вод $i$ омочена... / Помагайбіг, водице-єлинице! / $\boldsymbol{E}$ ти в хоромій керниці, / Прибувай же ти в керниці, / Очищай же ти камінні береги, / Бо ти очищена з первовіку... [1, с. 11].

Знаходимо тексти українських замовлянь, в яких вжито прийом лексичної анафори - повторення на початку віршових рядків слів із метою посилення їхнього звучання, як-от: Може, з тяжкої роботи, / Може, 3 журби великої. / Може, з труда непосильного, / Може, приспано, / Може, з очей поганих, / Може, з важкої муки, / Може, з великої радості, / Може, з води, може, з вітру, / Може, взялося звечора, може, опівночі, / Може, при сході сония, може, з полудня, / Заклинаю... [1, с. 22].

Слова-повтори погані, Божі виконують роль епітетів та є засобами вираження експресії, наприклад: Заклинаю: погані очі, / Погані мислі, / Погані сустави - / Божими словами, / Божими молитвами / Відсилаю за червоне море, / За голубе море, / За чорне море, / За широке поле [1, с. 23].

Емоційне забарвлення слова переполох увиразнюють повтори зляканий, переляканий, як-от: Ти переполох зляканий, ти переполох переляканий... [1, с. 35], а прикметниковий суфікс -ущ передає значення інтенсивної ознаки: Bu, сухоти сухущі...[3, с. 52].

У текстах українських замовлянь часто трапляються повтори у вигляді звертань, у яких реалізується анафора - прийом винесення повторюваного слова на перше місце, наприклад: Кури, кури рябенькі! [3, с. 23]; Дубе, дубе! Ти чорний: у тебе, дубе, білая береза, у тебе дубочки синочки, а у березочки дочки [3, с. 23]; Сово, сово! У мене - син, а в тебе - дочка [3, с. 24]; Ви, ліси-лісища, ви, бори-борища, візьміть собі пристрітища і урочища, занесіте їх на пущзі, на нетрі і на сухі ліси, на бистрі води [3, с. 28]; Уроки, урочища, подіть собі на яри, на ліси дрімучі... [3, с. 35]; Пристріче, пристріче, добрий чоловіче! [3, с. 32]; Пристріт сніданковий, / Пристріт обідній, / Пристріт вечірній, / Пристрім полуночний, / Пристріт вітряний, / Пристріт віхровий... [3, с. 30]. Цей вид повтору реалізується як лексико-синтаксичний.

У текстах замовлянь спостерігаємо прийом анадиплозису прийому, під час якого слово, яким закінчується перша фраза, починається наступна, як-от: - Місяию молодий, на тобі хрест золотий. Ти мертвим світив? / - Світив. / - Мертвих бачив? / - Бачив [Замовляння, 49]; Трясу, трясу кладкою, кладка водою, а вода купиною, а купина чортами, а чорти козаком... [3, с. 76].

Повтор також реалізується у такій структурно-смисловій фігурі як $-405-$

() С. А. Шуляк, 2015. 
ампліфікація - нагнітання синонімічних рядів слів, наприклад: ... Bid усяких клопотів, скорботів, / Від усяких ножів, мечів, / Від усяких мимоходів, переходів, / Від усяких ляків, переляків, / Від усяких хвороб, / Вid злетворних вітрів... [1, с. 32].

Естетична функція повтору як художнього тропу прослідковується у таких рядках: Господи, допоможси! / В щасливу годину, / В щасливу хвилину, / В щиасливу секунду! [1, с. 31].

Іноді трапляються тексти замовлянь, у яких повторюються різні форми слів, тобто частин мови, які мають спільний корінь, як-от: $У$ вовка біль, у тигра біль, у слона біль, у гієни біль. Тільки у раба Божого (ім'я) зуби не боліли, ні одні, ні два, ні три, ні чотири, ні п'ять $і$ не всі, які єсть $i$ які будуть. У кота болі, а у раба Божого (ім'я) перестань боліти віднині до віку віків, все його життя від молодості до старості [3, с. 50]. Тут сполучаються іменник біль і дієслово боліти, пов'язані спільним коренем.

Використання поширених повторів, як-от: Іило сім попів, несло по сім ціпів, ішло сім попів, несло по семи грабель, ішло сім попів, несло по семи лопат, ішло сім попів, несло по семи метел, зостріли бешиху водяну, вітряну і пристрітну на рабу Божому (ім'ярек) [3, с. 55] надають висловлюванню рухливості, переконливості, адже відбувається тиск на слухача завдяки повтору уже сказаного.

Експресивного відтінку тексту надають повтори на кшталт: Ішла кам'яна баба з кам'яною дійницею на кам'яну гору кам'яних корів доїть [3, с. 42]; На Осіянській горі там стояв колодязь камінний; туди ішла дівка камінна, камінні й відра, камінний коромисел, камінна вона вся; коли вона відтіля води принесе, тоді з рожденого, нахрещеного раба Божого (...) кров потече [3, с. 43].

Підсилення семантики лексем на позначення чорного, червоного (красного), білого, сірого кольору відбувається у текстах, де функціонують повтори цих кольороназв, наприклад: На чорному морі / Чорний чоловік сидить, / Чорний вогонь горить. / Чорна виделка, чорна тарілка, / Чорний ніж, чорна печінка...[3, с. 31]; Було собі красне море. Їхав чоловік красним возом, красними волами, красні колеса, красне ярмо, красна війя, красні притики, красне море рубати, хрещеному, нарожденному, молитвенному Іванові кров замовляти [3, с. 39]; Йшла біла дівка / Білою дорогою: / Ніжки в неї білі, / Ручки в неї білі, / Голова в неї біла... [3, с. 60] та у замовлянні від більма: Їхав Юрій на білім коні, білі губи, білі зуби, сам білий, в біле одягся, білим підперезався, веде за собою три хорти: один білий, другий сірий, третій червоний. Білий більмо злиже, сірий сльозу, а червоний кров [3, с. 59]. Взаємодія лексичних та синтаксичних засобів забезпечує ๑) С. А. Шуляк, 2015. 
увиразнення, експресивне виділення лексичних одиниць.

Отже, повтор розглядається як своєрідний дієвий засіб посилення виразності мови в текстах українських замовлянь. Лексичний i синтаксичний повтор функціонують як структурно-семантичні засоби організації тексту. Повторення одиниць різних мовних рівнів сприяє вираженню оцінних значень ставлення до предмета мовлення. Відповідно до мети, яка має бути досягнута, у текстах замовлянь спостерігаємо розгортання подій, у яких наростають ознаки, надаючи тексту відповідного емоційного напруження. Подальші дослідження стосуватимуться визначення синонімічних явищ у структурі текстів українських замовлянь.

\section{Література}

1. Ви, зорі-зориці...Українська народна магічна поезія : (Замовляння) / [упоряд. М. Г. Василенка, Т. М. Шевчук ; передм. М. Г. Василенка]. - К. : Молодь, 1991. - 336 с.

2. Жук Т. В. Лексичний та синтаксичний повтор в українській народній творчості (на матеріалі українських народних казок) : автореф. дис. ... канд. філол. наук/ Т. В. Жук. - К., 2005. - 20 с.

3. Замовляння / [упоряд., передмова, примітки М. К. Дмитренка]. - К. : Видавець М. Дмитренко, 2007. - 124 с.

4. Потебня А. А. Из записок по русской грамматике / А. А. Потебня. - Харьков, 1899. - T. 3. - C. 279-292.

5. Словник тропів і стилістичних фігур / [автор-укладач В. Ф. Святовець]. - К. : ВЦ «Академія», 2011. - $176 \mathrm{c}$.

6. Українознавство : [посібник] / [уклад. : В. Я. Мацюк, В. Г. Пукач]. - К. : Зодіак - ЄКО, 1994. - 399 c.

7. Українська мова : Енциклопедія / [ред. кол. : В. М. Русанівський, О. О. Тараненко (співголови), М. П.Зяблюк та ін.]. - К., 2000. - 752 с.

Стаття надійшла до редакиї̈ 01.07.2015 p. 